\title{
Penampilan Tebu dari Benih Bagal dan Budchip pada Dua Tata Tanam di Lahan Kering
}

\section{Performance of Sugarcane Seedlings from Budsett and Budchip on Two Planting Arrangements in Upland}

\author{
Djumali ${ }^{*}$ Lestari, dan Supriyono
}

Balai Penelitian Tanaman Pemanis dan Serat

J1. Raya Karangploso Kotak Pos 199 Malang 65152, Indonesia

Diterima 26 September 2016/Disetujui 27 Maret 2017

\begin{abstract}
Sugarcane and replanting programs require a lot of seed cane and can not be fulfilled from budsetts. To fill up the gap the use of budchip seedlings is suggested. The appropriate planting arrangement for budchip seedling has not been studied thoroughly. The study was conducted at the Asembagus Experimental Station, Situbondo, East Java, from January to December 2014 for the plant cane (PC) and from January to December 2015 for ratoon cane (RC). Research was arranged in a randomized block design with three replications. The treatments consisted of (1) single budsett in single row planting, (2) double budsetts in double rows planting, (3) single budchip in single row planting, (4) single budchip in double rows planting, and (5) double budchips in double rows planting. The results showed the budchip seedling increase productivity 14.46$15.46 \%$, sugar yield $18.17-23.38 \%$, and profit $873 \%$ from budsett seedling. Double rows planting with budchip seedling increase productivity 52.11-61.01\%, sugar yield 48.51-61.84\%, and profit $603 \%$ from single row planting. Double rows planting suitable for budchip seedling is single budchip with productivity 52.53-88.30 ton ha ${ }^{-1}$, sugar yield 3.69-8.17 ton ha-1 and profit IDR 9, 123,000 ha per year.
\end{abstract}

Keywords: growth, planting material, productivity, Saccharum officinarum, sugar yield

\section{ABSTRAK}

Program bongkar ratoon dan perluasan areal tanam memerlukan benih tebu yang banyak dan tidak mampu dipenuhi dari benih bagal. Budchip merupakan bentuk benih tebu yang diperbanyak lebih cepat dibanding benih bagal. Tata tanam yang tepat untuk benih budchip belum diketahui sehingga perlu dilakukan penelitian. Penelitian dilakukan di Kebun Percobaan Asembagus, Kabupaten Situbondo, Jawa Timur, pada Januari-Desember 2014 untuk tanaman pertama (PC) dan Januari-Desember 2015 untuk tanaman ratoon (RC). Penelitian disusun dalam rancangan acak kelompok, dengan tiga ulangan. Perlakuan terdiri dari (1) benih bagal tunggal dalam tanam juring tunggal, (2) benih bagal ganda dalam tanam juring ganda, (3) benih budchip tunggal dalam tanam juring tunggal, (4) benih budchip tunggal dalam tanam juring ganda, dan (5) benih budchip ganda dalam tanam juring ganda. Hasil penelitian menunjukkan benih budchip meningkatkan produktivitas 14.46-15.46\%, hasil hablur 18.17-23.38\%, dan keuntungan 873\% dari benih bagal. Tata tanam juring ganda benih budchip meningkatkan produktivitas 52.11-61.01\%, hasil hablur 48.51-61.84\%, dan keuntungan 603\% dari juring tunggal. Tata tanam juring ganda yang sesuai untuk benih budchip adalah tata tanam juring ganda benih tunggal dengan

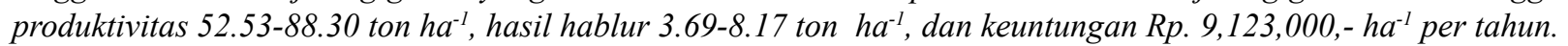

Kata kunci: bahan tanam, hasil hablur, pertumbuhan, produktivitas, Saccharum officinarum

\section{PENDAHULUAN}

Tebu (Saccharum officinarum L.) adalah tanaman penghasil gula di Indonesia. Pada tahun 2014, konsumsi gula nasional mencapai 5.72 juta ton, tahun 2015 meningkat menjadi 5.86 juta ton (Nusantara Sugar Community, 2016). Upaya yang dapat dilakukan diantaranya meningkatkan produksi gula atau menambah kuota impor gula.

\footnotetext{
* Penulis untuk korespondensi. e-mail: djumali_62@yahoo.com
}

Dalam rangka mencapai kemandirian pangan, pemerintah berupaya untuk memenuhi kebutuhan gula nasional melalui peningkatan produksi gula. Sampai dengan tahun 2014 produksi gula nasional masih sebesar 2.58 juta ton dari luas areal pengembangan tebu sekitar 479 ribu hektar dengan produktivitas hablur 5.4 ton $\mathrm{ha}^{-1}$. Kebutuhan gula tahun 2015 bisa terpenuhi bila hasil hablur mencapai 7.4 ton $\mathrm{ha}^{-1}$ dan penambahan areal baru seluas 300.7 ribu hektar (Ditjenbun, 2014). Program swasembada padi, jagung dan kedelai menyebabkan upaya perluasan areal tanam tebu sulit diwujudkan. Upaya pencapaian swasembada gula 
harus dilakukan melalui peningkatan hasil hablur menjadi 12.05 ton $\mathrm{ha}^{-1}$.

Salah satu penyebab rendahnya produktivitas tanaman tebu adalah penggunaan tanaman ratoon keempat dan seterusnya. Oleh karena itu pembatasan penggunaan tanaman ratoon sampai ratoon ketiga atau RC-3 diterapkan untuk meningkatkan produktivitas. Pembatasan tersebut menyebabkan dilakukan pembongkaran tanaman ratoon (bongkar ratoon) setiap tahun seluas $25 \%$ dari total luas lahan tebu di Indonesia. Kebutuhan benih yang diperlukan 6-8 ton ha-1 atau setara dengan 32 ribu bagal dua mata (Jain et al., 2014). Areal tebu pada tahun 2014 seluas 479 ribu hektar sehingga jumlah benih yang diperlukan kegiatan bongkar ratoon sebanyak 718-958 ribu ton atau setara 3.8 milyar bagal dua mata. Kebutuhan benih tersebut setara 8-10\% dari total luas lahan tanaman produksi (Jain et al., 2011). Oleh karena itu perlu dicarikan bentuk benih yang lebih cepat dan murah dalam penyediaannya.

Kemajuan teknologi perbanyakan benih tebu menghasilkan bentuk benih baru yang disebut budchip. Budchip berasal dari mata bagal yang diambil dan ditumbuhkan dalam media pembibitan selama dua bulan. Budchip berukuran ringan sehingga mampu menekan bobot benih 80\% (Jain et al., 2010). Penggunaan budchip mampu meningkatkan penyediaan benih enam kali lebih banyak dan meningkatkan produktivitas sebesar 20\% (Jain et al., 2014), dan menekan biaya produksi $16.7-20 \%$ (Singh dan Gurpreet, 2015). Benih budchip memerlukan air yang cukup selama 4-5 bulan pertama fase pertumbuhan sehingga sesuai untuk lahan beririgasi (Rahman et al., 2008; Hossain et al., 2009).

Di India pengembangan tebu dari benih budchip menggunakan jarak antar barisan tanaman (PKP = pusat ke pusat) $150 \mathrm{~cm}$, sedangkan di Kolombia menggunakan PKP $180 \mathrm{~cm}$ (Shanty dan Ramanjaneyulu, 2014). Di Indonesia, benih budchip dicoba penggunaannya di lahan kering dengan waktu tanam pada awal hujan dan PKP 130 $\mathrm{cm}$. Produktivitas tebu yang diperoleh sama dengan tebu dari benih bagal. Di sisi lain penggunaan benih bagal pada tata tanam juring ganda benih ganda mampu meningkatkan produktivitas $132 \%$ dan hasil hablur $137 \%$ dari juring tunggalnya (Djumali et al., 2016). Sampai saat ini belum pernah dicoba penggunaan tata tanam juring ganda pada tebu yang berasal dari benih budchip. Oleh karena itu perlu dilakukan penelitian yang bertujuan untuk memperoleh tata tanam yang tepat bagi benih budchip agar diperoleh peningkatan produktivitas dan hasil hablur.

\section{BAHAN DAN METODE}

Penelitian dilakukan di Kebun Percobaan Asembagus, Kabupaten Situbondo, Jawa Timur pada Januari sampai dengan Desember 2014 untuk tanaman PC dan Januari sampai dengan Desember 2015 untuk tanaman RC. Bahan tanam yang digunakan benih bagal bermata dua dan budchip yang berasal dari tebu varietas Bululawang berumur 6 bulan, pupuk kandang, pupuk majemuk NPK, pupuk tunggal ZA dan bahan pembantu lainnya. Benih budchip diperoleh dari mata tebu yang ditumbuhkan terlebih dahulu dalam media pasir selama 2 minggu dan selanjutnya dipindah ke nampan pembibitan. Pemeliharaan di nampan pembibitan dilakukan selama 2 bulan. Benih budchip yang ditanam di lapangan dipilih benih yang tumbuh normal, sehat dan seragam (Gambar 1). Curah hujan selama penelitian berlangsung seperti tertera pada Tabel 1.

Percobaan disusun dalam rancangan acak kelompok dan diulang 3 kali. Perlakuan yang dicoba meliputi 1) benih bagal tunggal ( 3 benih $\mathrm{m}^{-1}$ juring) dalam tata tanam juring tunggal, 2) benih bagal ganda ( 6 benih $\mathrm{m}^{-1}$ juring) dalam tata tanam juring ganda, 3) benih budchip tunggal (2 benih $\mathrm{m}^{-1}$ juring) dalam tata tanam juring tunggal, 4) benih budchip tunggal dalam tata tanam juring ganda, dan 5) benih budchip ganda (4 benih $\mathrm{m}^{-1}$ juring) dalam tata tanam juring ganda. Jarak PKP untuk perlakuan 1 dan 3 (tata tanam juring
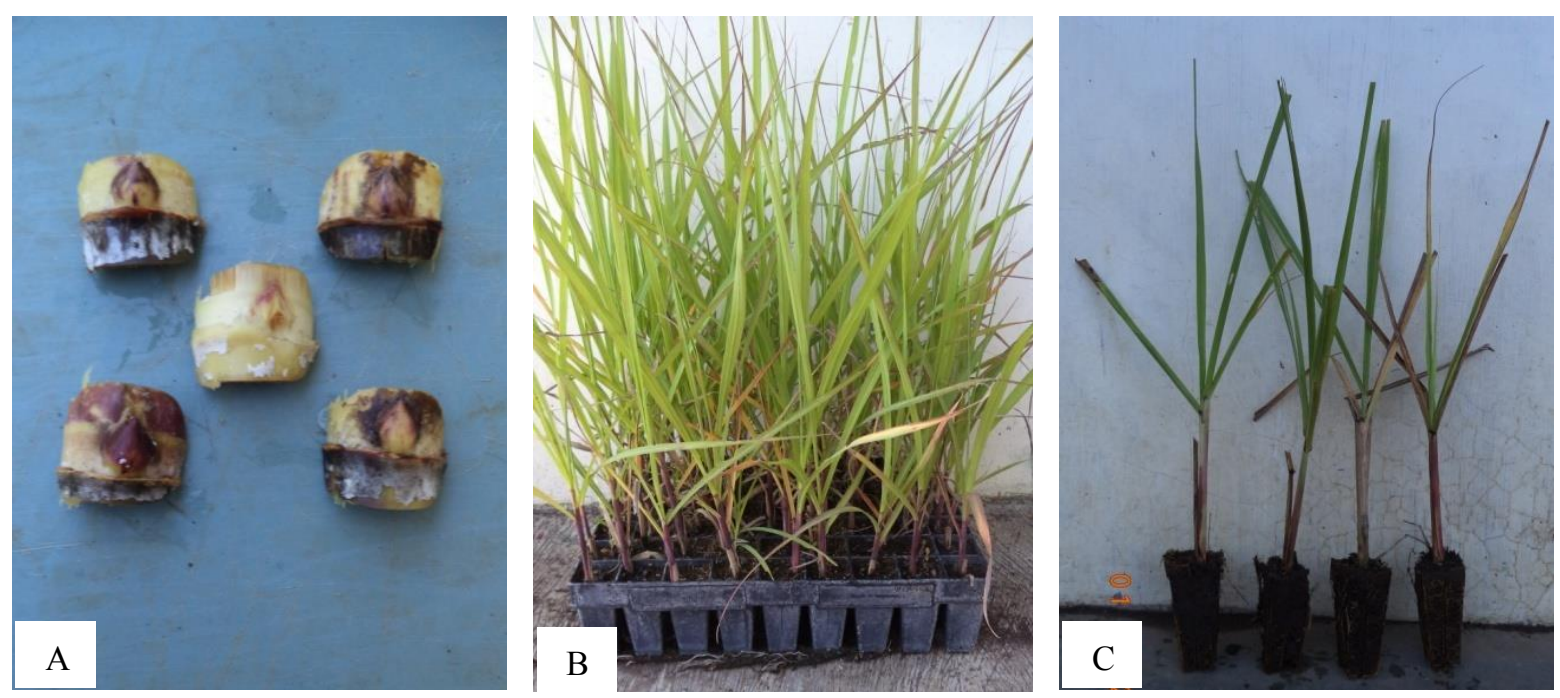

Gambar 1. Benih budchip yang siap ditumbuhkan di media pasir (A), dipelihara dalam nampan pembibitan (B), dan siap ditanam di lapangan $(\mathrm{C})$ 
Djumali et al. / J. Agron. Indonesia 45(3):299-307

Tabel 1. Curah hujan di Kebun Percobaan Asembagus, Situbondo, selama tahun 2014-2015

\begin{tabular}{lcccc}
\hline \multirow{2}{*}{ Bulan } & \multicolumn{2}{c}{ Tahun 2014 } & \multicolumn{2}{c}{ Tahun 2015 } \\
\cline { 2 - 5 } & $\begin{array}{c}\text { Curah hujan } \\
(\mathrm{mm})\end{array}$ & $\begin{array}{c}\text { Hari hujan } \\
\text { (hari) }\end{array}$ & $\begin{array}{c}\text { Curah hujan } \\
(\mathrm{mm})\end{array}$ & $\begin{array}{c}\text { Hari hujan } \\
\text { (hari) }\end{array}$ \\
\hline Januari & 175.8 & 13 & 146.0 & 14 \\
Februari & 155.3 & 10 & 130.0 & 13 \\
Maret & 17.3 & 4 & 88.7 & 8 \\
April & 38.1 & 7 & 164.1 & 11 \\
Mei & 42.4 & 5 & 15.8 & 1 \\
Juni & 0.7 & 1 & 0.0 & 0 \\
Juli & 0.0 & 0 & 0.0 & 0 \\
Agustus & 0.0 & 0 & 0.0 & 0 \\
September & 0.0 & 0 & 0.0 & 0 \\
Oktober & 0.0 & 0 & 0.0 & 0 \\
November & 0.0 & 0 & 0.0 & 0 \\
Desember & 21.4 & 11 & 81.1 & 7 \\
\hline
\end{tabular}

tunggal) selebar $130 \mathrm{~cm}$ dan untuk perlakuan 2, 4 dan 5 (tata tanam juring ganda) selebar 50/170 cm (Gambar 2).

Sebelum ditanami tebu, juringan pada setiap perlakuan diberi pupuk kandang berdosis 5 ton $\mathrm{ha}^{-1}$ dan diaplikasi karbofuran untuk mencegah serangan rayap. Benih tebu ditanam dalam juringan atau lubang tanam yang tersedia. Lahan diantara juringan tebu ditanami kacang tanah seminggu setelah tanam tebu.

Pemeliharaan tanaman meliputi penyulaman, pemupukan, penyiangan, pembumbunan, dan pengairan. Penyulaman dilakukan 2 minggu setelah tanam dengan menanam benih yang tersedia sampai populasi tanaman menjadi sesuai perlakuan. Pemupukan untuk tanaman PC dilakukan dua kali yakni pada saat tanaman berumur 3-4 minggu untuk pupuk majemuk dan 3 bulan setelah tanam untuk pupuk ZA, sedangkan untuk tanaman RC dilakukan sekali yakni pada saat tanaman berumur satu bulan setelah kepras. Pemupukan dilakukan secara larikan berjarak 10 $\mathrm{cm}$ dari larikan pangkal batang tanaman. Dosis pupuk yang digunakan untuk tata tanam juring tunggal adalah $96 \mathrm{~kg} \mathrm{~N}+$ $48 \mathrm{~kg} \mathrm{P}_{2} \mathrm{O}_{5}+108 \mathrm{~kg} \mathrm{~K}_{2} \mathrm{O}+12 \mathrm{~kg} \mathrm{~S}+12 \mathrm{~kg} \mathrm{Si} \mathrm{ha}^{-1}$ bersumber dari pupuk majemuk berformula $16 \mathrm{~N}: 8 \mathrm{P}: 18 \mathrm{~K}: 2 \mathrm{Si}: 2 \mathrm{~S}$ dan
$20 \mathrm{~kg} \mathrm{~N}+24 \mathrm{~kg} \mathrm{~S} \mathrm{ha}^{-1}$ bersumber dari pupuk ZA. Dosis pupuk untuk tata tanam juring ganda 1.6 kali dosis pupuk juring tunggal. Pembumbunan dilakukan 2 kali dengan cara menarik tanah di sekitar juringan ke atas juringan pada saat pemupukan. Pengairan dilakukan pada tanaman PC di bulan Maret sebanyak 2 kali, bulan Mei sebanyak satu kali dan bulan Juni sebanyak 2 kali.

Pengamatan pertumbuhan yang mencakup tinggi tanaman, panjang dan diameter batang dilakukan menjelang panen. Pengamatan komponen produksi yang meliputi jumlah tanaman, bobot batang, produktivitas, rendemen dan hasil hablur dilakukan pada saat panen. Khusus pengamatan rendemen dilakukan di Pabrik Gula Asembagus, Situbondo. Panen tebu PC dilakukan pada umur 9 bulan, sedangkan tebu RC pada umur 11 bulan. Data yang diperoleh dianalisis sidik ragam kontras untuk membandingkan penampilan tebu antara (1) benih bagal dengan benih budchip, (2) tata tanam juring tunggal dengan juring ganda pada benih bagal, (3) tata tanam juring tunggal dengan juring ganda pada benih budchip, dan (4) benih budchip tunggal dengan benih budchip ganda pada tata tanam juring ganda. Analisis usahatani dilakukan dengan menghitung seluruh biaya
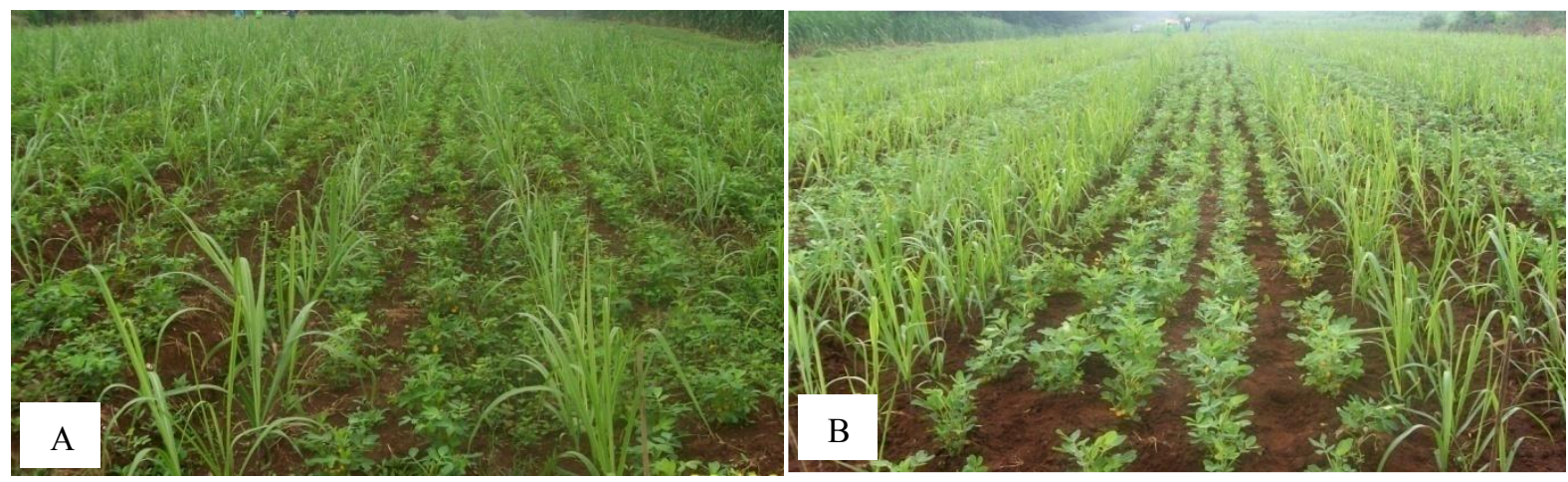

Gambar 2. Tata tanam tebu juring tunggal PKP $130 \mathrm{~cm}$ (A) dan juring ganda PKP 50/170 cm (B) 
usahatani yang dikeluarkan (bibit + pupuk serta tenaga kerja) dan penerimaan yang diperoleh. Keuntungan dihitung dari selisih antara penerimaan dan biaya yang dikeluarkan.

\section{HASIL DAN PEMBAHASAN}

Penampilan tebu yang mencakup panjang dan diameter batang, jumlah batang, bobot batang, produktivitas, rendemen dan hasil hablur di lahan kering dipengaruhi oleh bentuk benih dan tata tanam, baik pada tanaman PC maupun RC (Tabel 2-5). Secara umum benih budchip yang ditanam dengan tata tanam juring ganda menghasilkan penampilan tebu yang lebih baik dibanding dengan perlakuan lainnya.

\section{Penampilan Tebu yang Berasal dari Benih Bagal dan Budchip}

Penggunaan benih berbentuk budchip mampu meningkatkan jumlah batang sebesar 5.30-5.98\% dari benih bagal (Tabel 2). Secara umum pertumbuhan batang utama tanaman tebu yang berasal dari benih budchip mengalami hambatan selama fase pertumbuhan awal sehingga muncul anakan (Khalid et al., 2015). Jumlah anakan yang muncul $55 \%$ lebih banyak dibanding dari benih bagal (Loganandhan et al., 2012). Dalam kondisi nutrisi dan ruang tumbuh tidak menjadi faktor pembatas, jumlah anakan berkorelasi positif dengan jumlah batang yang dihasilkan (Gilbert et al., 2008; Nurhayati et al., 2013). Oleh karena itu benih budchip menghasilkan jumlah batang lebih banyak dibanding benih bagal.

Penggunaan benih budchip mampu meningkatkan bobot batang sebesar 4.25-5.58\% dari benih bagal (Tabel 2). Benih budchip mampu menghasilkan pertumbuhan anakan lebih serempak dibanding benih bagal (Loganandhan et al., 2012). Pertumbuhan anakan yang serempak menghasilkan bobot batang yang lebih seragam dibanding pertumbuhan anakan yang tidak serempak (Munsif et al., 2015). Keseragaman bobot batang tebu dalam satu rumpun berpengaruh positif terhadap rerata bobot batang (Singh dan Gurpreet, 2015). Oleh karena itu benih budchip menghasilkan bobot batang tebu lebih tinggi dibanding benih bagal.
Penggunaan benih budchip mampu meningkatkan produktivitas tebu sebesar $14.46-15.46 \%$ dari benih bagal (Tabel 2). Bobot batang dan jumlah batang merupakan komponen utama penyusun produktivitas tebu. Kedua komponen tersebut berkorelasi positif dengan produktivitas tebu (Soomro et al., 2012; Tyagi et al., 2013). Benih budchip menghasilkan bobot batang tinggi dan jumlah batang banyak sehingga menghasilkan produktivitas tinggi. Hasil penelitian Jain et al. (2014) dan Loganandhan et al. (2012) memperlihatkan penggunaan benih budchip mampu meningkatkan produktivitas 20-49\% dari benih bagal.

Perbedaan bentuk benih tebu tidak mempengaruhi rendemen yang dihasilkan (Tabel 2). Rendemen tebu lebih banyak dipengaruhi oleh varietas tanaman, nutrisi dan kelembaban tanah (Bahrani et al., 2009; Keshavaiah et al., 2012). Hasil penelitian Khalid et al. (2015) memperlihatkan ketiadaan pengaruh penggunaan benih budchip terhadap rendemen tebu.

Penggunaan benih budchip mampu meningkatkan hasil hablur sebesar 18,17-23.38\% dari benih bagal (Tabel 2). Produktivitas tebu dan rendemen merupakaan salah faktor utama penyusun hasil hablur. Kedua komponen tersebut berkorelasi positif dengan hasil hablur (Soomro et al., 2012). Benih budchip menghasilkan produktivitas lebih tinggi dengan rendemen yang tidak berbeda dengan benih bagal sehingga memperoleh hasil hablur yang lebih tinggi dibanding benih bagal.

\section{Penampilan Tebu yang Berasal dari Benih Bagal pada Dua Tata Tanam}

Perbedaan tata tanam tebu berasal dari benih bagal menyebabkan perbedaan jumlah batang yang diperoleh (Tabel 3). Tata tanam juring ganda benih ganda mampu meningkatkan jumlah batang sebesar 8.77-16.39\%. Penggunaan benih ganda dalam tata tanam juring ganda menyebabkan peningkatan populasi tanaman (Ehsanullah et al., 2011). Populasi tanaman tinggi tidak mengganggu pertumbuhan batang tebu bila kebutuhan energi cahaya dan ketersediaan nutrisi dalam tanah terpenuhi (Manimaran et al., 2009). Tata tanam juring ganda dengan dosis pupuk dua kali dosis tata tanam juring tunggal mampu meningkatkan energi

Tabel 2. Penampilan tebu PC dan RC yang berasal dari benih bagal dan budchip

\begin{tabular}{|c|c|c|c|c|}
\hline \multirow{2}{*}{ Peubah penampilan } & \multicolumn{2}{|c|}{ Tanaman pertama (PC) } & \multicolumn{2}{|c|}{ Tanaman ratoon $(\mathrm{RC})$} \\
\hline & Bagal & Budchip & Bagal & Budchip \\
\hline Panjang batang $(\mathrm{cm})$ & $151.46 \mathrm{a}$ & $150.54 \mathrm{a}$ & $216.90 \mathrm{a}$ & $215.94 \mathrm{a}$ \\
\hline Diameter batang (mm) & $27.26 \mathrm{a}$ & $27.79 \mathrm{a}$ & $29.90 \mathrm{~b}$ & $31.05 \mathrm{a}$ \\
\hline Bobot batang (g) & $844.54 b$ & $891.63 a$ & $879.39 b$ & $916.77 \mathrm{a}$ \\
\hline Jumlah batang (ribu batang ha-1) & $62.61 b$ & $65.93 \mathrm{a}$ & $83.92 b$ & $88.94 \mathrm{a}$ \\
\hline Produktivitas (ton ha' ${ }^{-1}$ ) & $47.91 b$ & $55.31 \mathrm{a}$ & $67.02 b$ & $76.71 \mathrm{a}$ \\
\hline Rendemen $(\%)$ & $6.80 \mathrm{~b}$ & $7.26 \mathrm{a}$ & $9.12 \mathrm{a}$ & $9.40 \mathrm{a}$ \\
\hline Hasil hablur (ton ha-1) & $3.25 b$ & $4.01 \mathrm{a}$ & $6.11 \mathrm{~b}$ & $7.22 \mathrm{a}$ \\
\hline
\end{tabular}

Keterangan: Angka yang didampingi huruf sama dalam baris yang sama berarti tidak berbeda nyata pada uji ortogonal kontras taraf $5 \%$ 
cahaya tersedia 9.7-15.1\% dan ketersediaan nutrisi dalam tanah (Djumali et al., 2016). Dalam kondisi pertumbuhan batang yang tidak berbeda, peningkatan populasi tanaman menyebabkan peningkatan jumlah batang (Suggu et al., 2010). Tata tanam juring ganda menggunakan populasi tanaman tinggi sehingga menghasilkan jumlah batang lebih banyak dibanding tata tanam juring tunggal.

Tata tanam juring ganda dengan benih ganda mampu meningkatkan produktivitas tebu sebesar 37.7-38.5\% dari juring tunggal (Tabel 3). Peningkatan jumlah batang tanpa diikuti oleh penurunan bobot batang menyebabkan peningkatan produktivitas tebu (Ghaffar et al., 2012). Sajjad et al. (2014) memperlihatkan penggunaan populasi tanaman yang tinggi mampu meningkatkan produktivitas tebu $27.5 \%$. Oleh karena itu, tata tanam juring ganda benih ganda memperoleh produktivitas lebih tinggi dibanding tata tanam juring tunggal.

Tata tanam juring ganda benih ganda mampu meningkatkan hasil hablur sebesar $36.36-38.87 \%$ dari juring tunggal (Tabel 3). Tata tanam tidak mempengaruhi rendemen yang diperoleh (Soomro et al., 2009; Singh et al., 2012). Dalam kondisi rendemen yang tidak berbeda, hasil hablur ditentukan oleh produktivitas tebu. Tata tanam juring ganda benih ganda menghasilkan produktivitas tebu lebih tinggi sehingga hasil hablur yang diperolehnya juga lebih tinggi dibanding tata tanam juring tunggal.

\section{Penampilan Tebu yang Berasal dari Benih Budchip pada Dua Tata Tanam}

Perbedaan tata tanam tebu dari benih budchip menghasilkan perbedaan jumlah batang yang diperoleh (Tabel 4). Tata tanam juring ganda mampu meningkatkan jumlah batang sebesar 16.99-35.56\%. Benih budchip mempunyai anakan banyak dengan pertumbuhan serempak. Untuk mendukung pertumbuhan anakan tersebut diperlukan energi cahaya yang banyak (Shanty dan Muthusamy, 2012). Tata tanam juring ganda merupakan salah satu cara untuk memperlebar PKP sehingga dapat meningkatkan ketersediaan energi cahaya bagi tanaman (Rana et al. 2006; Dantata, 2014). Chatta et al. (2007) dan Singh et al. (2012) memperlihatkan peningkatan PKP diikuti oleh peningkatan jumlah anakan. Jumlah anakan berkorelasi positif dengan jumlah batang (Munsif et al., 2015). PKP lebar menghasilkan jumlah batang lebih banyak dibanding PKP sempit (Loganandhan et al., 2012; Patel et al., 2014). Singh et al. (2012) dan Sajjad et al. (2014) memperlihatkan penggunaan tata tanam juring ganda mampu meningkatkan jumlah batang $6.1-17.8 \%$ dari juring tunggal.

Tata tanam juring ganda mampu meningkatkan bobot sebesar $4.88-17.31 \%$ dari tata tanam juring tunggal (Tabel 4). Peningkatan intensitas cahaya dalam tajuk menyebabkan peningkatan laju fotosintesis tanaman (Zhu et al., 2010;

Tabel 3. Penampilan tebu PC dan RC yang berasal dari benih bagal pada tata tanam juring tunggal dan tata tanam juring ganda

\begin{tabular}{|c|c|c|c|c|}
\hline \multirow{2}{*}{ Peubah penampilan } & \multicolumn{2}{|c|}{ Tanaman pertama (PC) } & \multicolumn{2}{|c|}{ Tanaman ratoon $(\mathrm{RC})$} \\
\hline & Juring tunggal & Juring ganda & Juring tunggal & Juring ganda \\
\hline Panjang batang $(\mathrm{cm})$ & $149.07 \mathrm{a}$ & $153.84 \mathrm{a}$ & $212.74 a$ & $221.07 \mathrm{a}$ \\
\hline Diameter batang (mm) & $27.29 \mathrm{a}$ & $27.22 \mathrm{a}$ & $30.10 \mathrm{a}$ & $29.70 \mathrm{a}$ \\
\hline Bobot batang (g) & $844.66 a$ & $844.43 a$ & $868.74 a$ & $900.04 \mathrm{a}$ \\
\hline Jumlah batang (ribu batang ha-1) & $57.83 b$ & $67.31 \mathrm{a}$ & $64.91 b$ & $87.40 \mathrm{a}$ \\
\hline Produktivitas (ton ha-1) & $40.17 b$ & $55.65 \mathrm{a}$ & $56.39 b$ & $77.65 \mathrm{a}$ \\
\hline Rendemen $(\%)$ & $6.82 \mathrm{a}$ & $6.77 \mathrm{a}$ & $9.09 \mathrm{a}$ & $9.15 \mathrm{a}$ \\
\hline Hasil hablur (ton ha' ${ }^{-1}$ ) & $2.75 b$ & $3.75 \mathrm{a}$ & $5.12 \mathrm{~b}$ & $7.11 \mathrm{a}$ \\
\hline
\end{tabular}

Keterangan: Angka yang didampingi huruf sama dalam baris yang sama berarti tidak berbeda nyata pada uji ortogonal kontras taraf $5 \%$

Tabel 4. Penampilan tebu PC dan RC yang berasal dari benih budchip pada dua tata tanam

\begin{tabular}{lcccc}
\hline \multirow{2}{*}{ Peubah penampilan } & \multicolumn{2}{c}{ Tanaman pertama (PC) } & \multicolumn{2}{c}{ Tanaman ratoon (RC) } \\
\cline { 2 - 5 } & Juring tunggal & Juring ganda & Juring tunggal & Juring ganda \\
\hline Panjang batang $(\mathrm{cm})$ & $145.29 \mathrm{a}$ & $153.17 \mathrm{a}$ & $202.13 \mathrm{~b}$ & $222.84 \mathrm{a}$ \\
Diameter batang (mm) & $26.66 \mathrm{~b}$ & $28.35 \mathrm{a}$ & $31.27 \mathrm{a}$ & $30.94 \mathrm{a}$ \\
Bobot batang $(\mathrm{g})$ & $877.37 \mathrm{~b}$ & $920.15 \mathrm{a}$ & $821.91 \mathrm{~b}$ & $964.20 \mathrm{a}$ \\
Jumlah batang (ribu batang ha-1) & $53.30 \mathrm{~b}$ & $72.25 \mathrm{a}$ & $80.43 \mathrm{~b}$ & $93.15 \mathrm{a}$ \\
Produktivitas (ton ha ${ }^{-1}$ ) & $41.05 \mathrm{~b}$ & $62.44 \mathrm{a}$ & $54.53 \mathrm{~b}$ & $87.80 \mathrm{a}$ \\
Rendemen (\%) & $7.38 \mathrm{a}$ & $7.20 \mathrm{a}$ & $9.37 \mathrm{a}$ & $9.42 \mathrm{a}$ \\
Hasil hablur (ton ha ${ }^{-1}$ ) & $3.03 \mathrm{~b}$ & $4.50 \mathrm{a}$ & $5.11 \mathrm{~b}$ & $8.27 \mathrm{a}$ \\
\hline
\end{tabular}

Keterangan: Angka yang didampingi huruf sama dalam baris yang sama berarti tidak berbeda nyata pada uji ortogonal kontras taraf 5\% 
Liu et al., 2012) sehingga pertumbuhan tebu mengalami peningkatan (Samui et al., 2014). Ghaffar et al. (2012) dan Shakoor-Ruk et al. (2014) menunjukkan peningkatan PKP diikuti peningkatan bobot batang.

Tata tanam juring ganda mampu meningkatkan produktivitas dan hasil hablur masing-masing sebesar 52.1161.01 dan 48.51-61.84\% (Tabel 4). Peningkatan jumlah batang tebu dan bobot batang menyebabkan peningkatan produktivitas tebu (Khalid et al., 2015). Tata tanam yang menghasilkan jumlah dan bobot batang yang tinggi akan diikuti oleh produktivitas tebu yang tinggi pula. Penggunaan PKP $150 \mathrm{~cm}$ pada tebu yang berasal dari benih budchip menghasilkan jumlah batang dan bobot batang yang tinggi dan diikuti oleh peningkatan produktivitas sebesar 20\% dari PKP $120 \mathrm{~cm}$ (Loganandhan et al., 2012). Singh et al. (2012) dan Sajjad et al. (2014) menunjukkan penggunaan juring ganda mampu meningkatkan produktivitas tebu 7.7-27.5\% tanpa mempengaruhi rendemen.

\section{Penampilan Tebu Berasal dari Dua Populasi Benih Budchip pada Tata Tanam Juring Ganda}

Peningkatan populasi benih budchip dari 2 benih menjadi 4 benih $\mathrm{m}^{-1}$ juring pada tanaman PC diikuti oleh peningkatan bobot dan jumlah batang masing-masing sebesar 19.95 dan 12.38\% (Tabel 5). Penggunaan populasi benih tinggi menghasilkan kepadatan tanaman yang tinggi bila disertai dengan penerimaan intensitas cahaya yang cukup (Patel et al., 2014). Dalam kondisi nutrisi dalam tanah yang bukan merupakan faktor pembatas, kepadatan tanaman tinggi menghasilkan jumlah dan bobot batang yang tinggi (Ehsanullah et al., 2011).

Peningkatan populasi benih budchip dari 2 benih menjadi 4 benih $\mathrm{m}^{-1}$ juring pada tanaman PC diikuti oleh peningkatan produktivitas dan hasil hablur masing-masing sebesar 37.75 dan $44.17 \%$ (Tabel 5). Hal ini terjadi sebagai akibat peningkatan jumlah dan bobot batang yang diperoleh akibat peningkatan jumlah benih yang digunakan.

Peningkatan populasi benih budchip dari 2 benih menjadi 4 benih $\mathrm{m}^{-1}$ juring pada tanaman RC tidak diikuti oleh peningkatan bobot dan jumlah batang, produktivitas dan hasil hablur (Tabel 5). Tanaman RC menghasilkan anakan yang lebih banyak dibanding tanaman PC (ElGeddawy et al., 2002; Bhullar et al., 2008). Penggunaan populasi benih tinggi pada tanaman RC menghasilkan anakan yang terlalu banyak. Jumlah anakan terlalu banyak menyebabkan banyak anakan tidak dapat tumbuh secara normal bahkan mati (Babu et al., 2007). Dalam kondisi yang demikian intensitas cahaya merupakan faktor pembatas bagi pertumbuhan anakan tebu. Oleh karena kedua populasi benih ditanam pada satu jenis tata tanam maka jumlah dan bobot batang yang diperoleh tidak ada perbedaan. Dengan demikian, produktivitas dan hasil hablur yang diperoleh juga tidak ada perbedaan.

\section{Analisis Usahatani}

Semua perlakuan selama tahun pertama (PC) mengalami kerugian (Tabel 6) sebagai akibat hasil hablur yang rendah dan adanya biaya benih. Waktu tanam yang terlambat menyebabkan ketersediaan air selama fase pertumbuhan batang tebu sangat terbatas (Tabel 1) dan umur panen yang pendek (9 bulan) sehingga produktivitas dan rendemen yang dihasilkan menjadi rendah. Keuntungan usahatani tebu baru diperoleh setelah tahun kedua (RC1) sebagai akibat tidak ada biaya benih, olah tanah dan tanam serta hasil hablur yang tinggi. Waktu kepras yang dilakukan pada bulan November 2014 menyebabkan fase pertumbuhan batang terjadi selama musim hujan sehingga diperoleh produktivitas tebu yang tinggi.

Rerata keuntungan tertinggi (sembilan juta seratus duapuluh tiga ribu rupiah $\mathrm{ha}^{-1}$ per tahun) diperoleh benih budchip tunggal yang ditanam dalam tata tanam juring ganda. Hal ini terjadi sebagai akibat hasil hablur yang diperoleh tergolong tinggi dan biaya benih yang lebih rendah dibanding benih budchip ganda. Penggunaan benih budchip menyebabkan biaya benih lebih tinggi dibanding biaya benih bagal. Hasil hablur yang rendah pada perlakuan benih budchip yang ditanam dalam tata tanam juring tunggal menyebabkan perlakuan tersebut tidak menguntungkan. Demikian pula penggunaan benih budchip ganda menyebabkan biaya benih sangat tinggi sehingga keuntungan yang diperoleh tidak sebesar benih tunggal (Tabel 6).

Tabel 5. Penampilan tanaman tebu PC dan RC yang berasal dari dua populasi benih budchip pada tata tanam juring ganda

\begin{tabular}{lcccc}
\hline \multirow{2}{*}{ Peubah penampilan } & \multicolumn{2}{c}{ Tanaman pertama (PC) } & \multicolumn{2}{c}{ Tanaman ratoon (RC) } \\
\cline { 2 - 5 } & Benih tunggal & Benih ganda & Benih tunggal & Benih ganda \\
\hline Panjang batang (cm) & $150.71 \mathrm{a}$ & $155.63 \mathrm{a}$ & $225.46 \mathrm{a}$ & $220.23 \mathrm{a}$ \\
Diameter batang (mm) & $27.62 \mathrm{~b}$ & $29.08 \mathrm{a}$ & $31.25 \mathrm{a}$ & $30.62 \mathrm{a}$ \\
Bobot batang (g) & $836.69 \mathrm{~b}$ & $1003.60 \mathrm{a}$ & $976.00 \mathrm{a}$ & $952.39 \mathrm{a}$ \\
Jumlah batang (ribu batang ha-1) & $68.04 \mathrm{~b}$ & $76.46 \mathrm{a}$ & $92.58 \mathrm{a}$ & $93.72 \mathrm{a}$ \\
Produktivitas (ton ha ${ }^{-1}$ ) & $52.53 \mathrm{~b}$ & $72.36 \mathrm{a}$ & $88.30 \mathrm{a}$ & $87.30 \mathrm{a}$ \\
Rendemen (\%) & $7.07 \mathrm{a}$ & $7.33 \mathrm{a}$ & $9.25 \mathrm{a}$ & $9.59 \mathrm{a}$ \\
Hasil hablur (ton ha (1) $^{-1}$ & $3.69 \mathrm{~b}$ & $5.32 \mathrm{a}$ & $8.17 \mathrm{a}$ & $8.37 \mathrm{a}$ \\
\hline
\end{tabular}

Keterangan: Angka yang didampingi huruf sama dalam baris yang sama berarti tidak berbeda nyata pada uji ortogonal kontras taraf $5 \%$ 
Djumali et al. / J. Agron. Indonesia 45(3):299-307

Tabel 6. Biaya, penerimaan dan keuntungan yang diperoleh usaha tani tebu pada berbagai perlakuan pada PC dan RC-1

\begin{tabular}{|c|c|c|c|c|c|c|c|c|c|c|c|}
\hline \multirow{3}{*}{ Perlakuan } & \multicolumn{6}{|c|}{ Biaya $\left(\operatorname{Rp} 1000,-\right.$ ha $\left.^{-1}\right)$} & \multirow{2}{*}{\multicolumn{2}{|c|}{$\begin{array}{c}\text { Penerimaan } \\
\left(\mathrm{Rp} 1000,-\mathrm{ha}^{-1}\right)\end{array}$}} & \multirow{2}{*}{\multicolumn{2}{|c|}{ 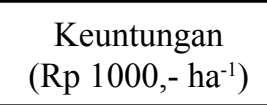 }} & \multirow[b]{3}{*}{ Rerata } \\
\hline & \multicolumn{3}{|c|}{$\mathrm{PC}$} & \multicolumn{3}{|c|}{ RC-1 } & & & & & \\
\hline & $\begin{array}{l}\text { Bibit+ } \\
\text { pupuk }\end{array}$ & $\begin{array}{c}\text { Tenaga } \\
\text { kerja }\end{array}$ & Total & Pupuk & $\begin{array}{c}\text { Tenaga } \\
\text { kerja }\end{array}$ & Total & $\mathrm{PC}$ & $\mathrm{RC}-1$ & $\mathrm{PC}$ & $\mathrm{RC}-1$ & \\
\hline $\mathrm{BG} 1+\mathrm{JT}$ & 14,903 & 14,547 & 29,450 & 6,903 & 14,547 & 21,450 & 17,787 & 33,116 & $-11,663$ & 11,663 & 2,000 \\
\hline $\mathrm{BG} 2+\mathrm{JG}$ & 23,845 & 16,997 & 40,842 & 11,045 & 16,997 & 28,042 & 24,255 & 45,987 & $-16,587$ & 17,946 & 679,000 \\
\hline $\mathrm{BC} 1+\mathrm{JT}$ & 18,567 & 14,687 & 33,254 & 6,903 & 14,687 & 21,590 & 19,598 & 33,051 & $-13,656$ & 11,461 & $-1,097$ \\
\hline $\mathrm{BC} 1+\mathrm{JG}$ & 18,567 & 16,497 & 35,064 & 6,903 & 16,497 & 23,400 & 23,867 & 52,844 & $-11,197$ & 29,444 & 9,123 \\
\hline $\mathrm{BC} 2+\mathrm{JG}$ & 34,373 & 19,647 & 54,020 & 11,045 & 19,647 & 30,692 & 34,410 & 54,137 & $-19,610$ & 23,445 & 1,918 \\
\hline
\end{tabular}

Keterangan: Proporsi gula untuk petani dan pabrik gula adalah 66:34, harga gula Rp 9,800,- $\mathrm{kg}^{-1}$, pupuk majemuk NPK Rp 6,000,- kg-1, pupuk ZA Rp 4,500,- $\mathrm{kg}^{-1}$, benih tebu Rp 8,000,000,- ha-1 dan benih budchip Rp. 600,- per batang. Biaya produksi belum termasuk sewa lahan. $\mathrm{BG} 1=$ benih bagal tunggal, $\mathrm{BG} 2=$ benih bagal ganda, $\mathrm{BC} 1=$ benih budchip tunggal, $\mathrm{BC} 2=$ benih budchip ganda, $\mathrm{JT}=$ juring tunggal, $\mathrm{JG}=$ juring ganda, $\mathrm{PC}=$ pertanaman pertama dan $\mathrm{RC}-1=$ pertanaman ratoon pertama

\section{KESIMPULAN}

Penggunaan benih budchip mampu meningkatkan produktivitas 14.46-15.46\%, hasil hablur 18.17-23.38\%, dan keuntungan $873 \%$ dari benih bagal. Benih budchip yang ditanam pada tata tanam juring ganda mampu meningkatkan produktivitas 52.11-61.01\%, hasil hablur 48.51-61.84\%, dan keuntungan $603 \%$ dari juring tunggal. Tata tanam juring ganda yang sesuai untuk benih budchip adalah tata tanam juring ganda benih tunggal dengan produktivitas 52.53-88.30 ton $\mathrm{ha}^{-1}$, hasil hablur 3.69-8.17 ton $\mathrm{ha}^{-1}$ dan keuntungan Rp. 9,123,000,- ha-1 per tahun.

\section{UCAPAN TERIMA KASIH}

Penulis mengucapkan terima kasih kepada Kepala Balai Penelitian Tanaman Pemanis dan Serat yang telah membiayai penelitian ini melalui DIPA tahun 2014 dan 2015. Terima kasih ditujukan kepada Kepala Kebun Asembagus beserta staf dan semua pihak yang telah membantu dalam pelaksanaan kegiatan penelitian ini.

\section{DAFTAR PUSTAKA}

Babu, V.S., M.M. Reddy, C.A. Subramayam, D. Balaguravaiah. 2007. Effect of integrated use of organic and inorganic fertilizer on productivity of sugarcane ratoon in Bangladesh. Sugar Tech. 2-3: $20-23$.

Bahrani, M.J., M. Shomeili, S.H. Zande-Parsa, A. Kamgar_ Haghighi. 2009. Sugarcane responses to irrigation and nitrogen in subtropical Iran. Iran Agric. Res. 27:17-26.

Bhullar, M.S., K.S. Thind, S.K. Uppal, K. Singh. 2008. Productivity, profitability and quality of sugarcane (Saccharum spp.) plant-ratoon system in relation to planting methods and seeding rate. Indian J. Agron. 53:195-199.
Chatta, M.U., A. Ali, M. Bilal. 2007. Influence of planting techniques on growth and yield of spring planted sugarcane (Saccharum officinarum L.). Pakistan J. Agric. Sci. 44:452-456.

Dantata, I.J. 2014. Effect of legume-based intercropping on crop yield : A review. Asian J. Agric. Food Sci. 2: 507-522.

Ditjenbun. 2014. Peningkatan produksi, produktivitas dan rendemen tanaman tebu untuk mencapai swasembada gula. Direktorat Jenderal Perkebunan, Jakarta.

Djumali, A.D. Khuluq, S. Mulyaningsih. 2016. Pertumbuhan dan produktivitas tebu pada beberapa paket tata tanam di lahan kering. J. Agron. Indonesia 44:211-219.

Ehsanullah, K. Jabran, M. Jamil, A. Ghaffar. 2011. Optimizing the sugarcane row spacing and seeding density to improve its yield and quality. Crop Environ. $2: 1-5$.

El-Geddawy, I.H., D.G. Darweish, A.A. El-Sherbing, E.A. El-Hady. 2002. Effect of row spacing and number of bud/seed setts on yield components of ratoon crops for some sugarcane cultivars ratoon. Pakistan Sugar J. 17:2-8.

Ghaffar, A., Ehsanullah, N. Akbar, S.H. Khan, K. Jabran, R.Q. Hashmi, A. Iqbal, M.A. Ali. 2012. Effect of trench spacing and micronutrients on growth and yield of sugarcane (Saccharum officinarum L.). Australian J. Crop Sci. 6:1-9.

Gilbert, R.A., D.R. Morris, C.R. Rainbolt, J.M. McCray, R.E. Perdomo, B. Eiland, G. Powell, G. Montes. 2008. Sugarcane response to millmud, fertilizer and soybean nutrient sources on sandy soil. Agron J. 100:845-854. 
Hossain, S.M.I., S.U.K. Eusufzai, M.A. Rahman. 2009. Effect of different irrigation levels on growth and yield parameters of sugarcane. Pakistan J. Agric. Res. 22:28-35.

Jain, R., S. Solomon, A.K. Shrivastava, A. Chandra. 2010. Sugarcane budchip : A promising seed material. Sugar Tech. 12:67-69.

Jain, R., S. Solomon, A.K. Shrivastava, A. Chandra. 2011. Effect of ethephon and calcium chloride on growth and biochemical attributes of sugarcane budchip. Acta Physiol. Plant. 33:905-910.

Jain, R., A. Chandra, A.K. Shrivastava, S. Solomon. 2014. Budchip technology for rapid seed multiplication and improving cane yield. Indian Farming 63:1-6.

Keshavaiah, K.V., Y.b. Palled, C. Shankariah, H.T. Channal, B.S. Nandihalli, K.S. Jagadeesha. 2012. Effect of nutrient management practices on nutrient dynamics and performance of sugarcane. Karnataka J. Agric. Sci. 25:187-192.

Khalid, S., F. Munsif, A. Ali, M. Ismail, N. Haq, S. Iqbal, M. Saeed. 2015. Evaluation of chip bud settling of sugarcane for enhancing yield to various row spacing. Inter. J. Agric. Envir. Res. 12:41-48.

Liu, T., F. Song, S. Liu, X. Zhu. 2012. Light interception and radiation use effeciency response to narrow-wide row planting patterns in maize. Australian J. Crop. Sci. 6:506-513.

Loganandhan, N., B. Gujja, V.V. Goud, U.S. Natarajan. 2012. Sustainable sugarcane initiative (SSI): a methodology of "more with less". Sugar Tech. 14: $1-5$.

Manimaran, S., D. Kalyanasundaram, S. Ramesh, K. Sivakumar. 2009. Maximizing sugarcane yield through efficient planting method and nutrient management practices. Sugar Technol. 11:395-397.

Munsif, F., K. Ali, S. Khalid, A. Ali, M. Ali, M. Ahmad, W. Ahmad, I. Ahmad, A. Basir. 2015. Efluence of row spacing on weed density, biomass and yield of chip bud settling of sugarcane. Pakistan J. Weed Sci. Res. 21:137-144.

Nusantara Sugar Community. 2016. Konsumsi gula putih dan gula rafinasi. J. Gula 30:22-23.

Nurhayati, A. Basit, Sunawan. 2013. Hasil tebu pertama dan keprasan serta efisiensi penggunaan hara $\mathrm{N}$ dan $\mathrm{S}$ akibat substitusi ammonium sulfat. J. Agron. Indonesia 41:54-61.
Patel, D., V.C. Raj, B. Tandel, B. Patel, D.N. Patel, V. Surve. 2014. Influence of planting distance and variety on growth of sugarcane and weed population under mechanization. J. Inter. Academic Res. Multidisc. 2:34-41.

Rahman, M.A., S.U.K. Eusufzai, S.S. Tabriz, S.M.I. Hossain. 2008. Optimization of irrigation levels for selected sugarcane varieties in AEZ-II of Bangladesh. The Agriculturists 6:99-107.

Rana, N.S., K. Sanjay, S.K. Saini, G.S. Panwar. 2006. Production potential and profitability of autumn sugarcane-based intercroping systems as influenced by intercrops and row spacing. Indian J. Agron. 51: 31-33.

Sajjad, M., A. Bari, M. Nawaz, S. Iqbal. 2014. Effect of planting pattern and nutrient management on yield spring planted sugarcane. Sarhad J. Agric. 30:67-71.

Samui, R.P., P.S. Kulkarni, M.V. Kamble, N.G. Vaidya. 2014. A critical evaluation of sugarcane yield variation as influenced by climatic parameters in Uttar Pradesh and Maharashtra States of India. Time J. Agric. Veter. Sci. 2:63-69.

Shakoor-Ruk, A., M.N. Kandhro, S. Khan-Baloch, S. UllahBaloch, A. Bakhsh-Baloch. 2014. Impact of sett placement method and row directions on growth and yield of sugarcane variety LRK-2001. Persian Gulf Crop Prot. 3:53-59.

Shanty, T.R., G.R. Muthusamy. 2012. Wider row spacing in sugarcane : A socio-economic performance analysis. Sugar Tech. 14:126-133.

Shanty, T.R., S. Ramanjaneyulu. 2014. Socio-economic performance analysis of sugarcane cultivation under sustainable sugarcane initiative method. Indian Res. J. Ext. Edu. 14:93-98.

Singh, G.J., K. Gurpreet. 2015. Infusion of single budchip planting technique for sugarcane propagation. Indian J. Econ. Dev. 11:227-232.

Singh, G.D., S.K. Saini, A. Bhatnagar, G. Singh. 2012. Effect of planting methods and irrigation scheduling on growth, yield and quality of spring planted sugarcane (Saccharum officinarum L.). Ann. Agric. Res. 33:21-24.

Soomro, A.F., M.Y. Arain, R.N. Panhwar, M.A. Rajput, N. Gujar. 2009. Effect of spacing and seed placement on yield and yield contributing characters of sugarcane variety Thatta-10 under agroecological conditions of Thatta. Pakistan J. Sci. 61:110-115. 
Soomro, A.F., S. Tunio, F.C. Oad, I. Rajper, M.I. Khuhro, M.Y. Arain. 2012. Effect of supplemental inorganic NPK and residual organic nutrients on sugarcane ratoon crop. Inter. J. Sci. Eng. Res. 3:1-11.

Suggu, A.G., E. Ahmad, H. Himayatullah, M. Ayaz, H.K. Ahmad, M. Aslam. 2010. Morphological responses of autum planted sugarcane to planting geometry and nutrient management on different soil under arid conditions. Pakistan Sugar J. 25:2-9.
Tyagi, V.K., S. Sharma, S.B. Bhardwaj. 2013. Pattern of association among cane yield, sugar yield and their components in sugarcane (Saccharum officinarum L.). J. Agric. Res. 50:29-38.

Zhu, X.G., S.P. Long, D.R. Ort. 2010. Improving photosynthetic efficiency for greater yield. Ann. Rev. Plant. Biol. 61:235-261. 